\title{
C-reactive protein as a prognostic marker of distraction osteogenesis disorders. Preliminary results
}

\author{
A.M. Aranovich, M.V. Stogov, N.V. Tushina, E.A. Kireeva
}

Ilizarov National Medical Research Centre for Traumatology and Orthopedics, Kurgan, Russian Federation

\begin{abstract}
The aim of this study was to assess the information value of the content of C-reactive protein (CRP) for predicting disorders of distraction osteogenesis. Materials and methods A retrospective analysis of the results of surgical lengthening of the bones of the lower extremities due to short stature was performed in 39 patients. There were two groups of patients. Thirteen patients (main group) had cystic cavities formed in the area of distraction regenerate by the end of the surgical lengthening. The formation of distraction regenerate ran without complications in 26 patients (comparison group). Results Before treatment, all patients in both groups had CRP levels not exceeding $6 \mathrm{mg} / \mathrm{l}$. On the 10th day after the onset of distraction, 15 patients of the comparison group had the CRP level equal to $6 \mathrm{mg} / \mathrm{l}$ or higher than (57.7 \% of all patients in this group). In the main group, the CRP level was equal or higher than $6 \mathrm{mg} / 1$ only in 3 patients ( $23.1 \%$ of all patients in the main group). The significance level of the differences was 0.041. Discussion A retrospective analysis of clinical data revealed that the CRP level at the beginning of the distraction stage in the range of up to $6 \mathrm{mg} / \mathrm{l}$ was associated with an increased likelihood of developing cystic cavities in the regenerate by the end of the lengthening stage. This test is acceptable for use in clinical practice. Conclusion Preservation of the level of CRP in the blood serum, not exceeding $6 \mathrm{mg} / \mathrm{l}$ within 10 days after the onset of distraction, is a prognostic sign indicating a high probability of disorders in the formation of distraction regenerate in the patients undergoing surgical lengthening of the lower limb bones with the Ilizarov method.
\end{abstract}

Keywords: distraction osteogenesis, laboratory diagnostics, C-reactive protein

Control of bone repair in the course of transosseous distraction osteosynthesis, developed by G.A. Ilizarov, is one of the key tasks ensuring the success of surgical treatment of orthopedic patients [1]. In this regard, the possibilities of using all known diagnostic methods (radiography, physiology, ultrasound, laboratory studies) have been shown [2-4].

Among the control tasks, prediction of distraction regenerate formation course stands out separately. The most suitable for these purposes are laboratory tests, among which the applicability of immunological [5, 6], biochemical [7, 8], hematological parameters [9], hemostasis parameters [10], growth factors [11-14] has been shown. Nevertheless, the protocol for applying the proposed technologies has been poorly developed [2].

The purpose of the study was to assess the informative value of C-reactive protein for predicting disorders of distraction osteogenesis.

\section{MATERIAL AND METHODS}

A retrospective analysis of the results of surgical lengthening of the bones of the lower extremities due to short stature was performed in 39 patients. All patients underwent lengthening with the Ilizarov method of transosseous distraction osteosynthesis.

The study is based on the data of a retrospective assessment of the medical records of all patients who underwent esthetic lengthening of the bones of the lower extremities. The level of C-reactive protein in their blood in the distraction phase was counted (total, 39 cases). The study was continuous, inclusion / exclusion criteria were not used. The same refers to the number of patients in the groups.

There were two groups of patients. Thirteen patients of the main group had cystic cavities formed in the area of the distraction regenerate to the end of surgical lengthening. It required additional measures to stimulate the formation of the regenerate.
Formation of distraction regenerate occurred without complications in 26 patients of the comparison group.

Both groups were comparable in terms of demographic and clinical parameters (Table 1). There were no significant differences between them.

In all patients, the concentration of C-reactive protein (CRP) was determined in blood serum on an automatic biochemical analyzer Hitachi / BM 902 (Japan) (registration number of the Ministry of Health of the Russian Federation 2000/564) using reagent kits of Vital Diagnostics (Russia).

The significance of differences between groups was assessed using the chi-square test. To calculate it, as well as to determine the informative value of the prognostic test, an online calculator was used (http:// medstatistic.ru/calculators/calchi.html).

The permission of the Ethics Committee of the Ilizarov Centre of the Ministry of Health of Russia was obtained. 
Comparison of groups

\begin{tabular}{|l|c|c|c|c|}
\hline \multicolumn{1}{|c|}{ Group } & Age, years & Gender & Method of lengthening & Magnitude of lengthening, $\mathrm{cm}$ \\
\hline Main group $(\mathrm{n}=13)$ & $25.7 \pm 7.0$ & M/F: 6/7 & MP/BM: $10 / 3$ & $6.38 \pm 1.62$ \\
\hline Comparison group $(\mathrm{n}=26)$ & $26.2 \pm 6.3$ & M/F: $12 / 14$ & MP/BM: $19 / 8$ & $6.28 \pm 1.82$ \\
\hline
\end{tabular}

Note: MP - polysegmental monflocal osteosynthesis; BM - bifocal monosegmental osteosynthesis.

\section{RESULTS}

Prior to treatment, all patients of both groups had CRP levels that did not exceed $6 \mathrm{mg} / \mathrm{l}$ (Table 2). A retrospective study found that the level of CRP statistically differed between groups on the 10th day after the onset of distraction. In particular, 15 patients of the comparison group had the CRP level equal or higher than $6 \mathrm{mg} / \mathrm{l}(57.7 \%$ of all patients in this group) whereas in the main group the CRP level was higher than $6 \mathrm{mg} / 1$ only in 3 patients $(23.1 \%$ of all patients in this group). The significance level of differences was 0.041 .

The data obtained show that maintaining the CRP level within the normal range in the first ten days of distraction is a prognostical significant sign of possible subsequent formation of cystic cavities in the distraction regenerate. The normalized value of correlation strength (Pearson's coefficient) between the risk factor (low CRP level up to 10 days of distraction) and the outcome (formation of a cyst in the distraction regenerate) is 0.440 . Such a correlation, according to the recommendations [15], is judged as relatively strong. The predictive value of a positive result of this test, expressed in calculating the odds ratio (OR \pm standard error), is $4.545 \pm 0.769$ (95\% CI: $1.007-20.508)$, with a separation point of $6 \mathrm{mg} / \mathrm{l}$.

Table 2

Content of C-reactive protein in the patients' blood serum

\begin{tabular}{|l|c|c|c|c|}
\hline \multirow{2}{*}{ Group } & \multicolumn{2}{|c|}{ Me (min-max) } & \multicolumn{2}{c|}{ Number of patients with CRP $\geqslant 6 \mathrm{mg} / \mathrm{l} /$ total of patients } \\
\cline { 2 - 4 } & Before treatment & Day 10 of distraction & Before treatment & Day 10 of distraction \\
\hline Main group & $0(0 \div 6)$ & $0(0 \div 42)$ & $0 / 13$ & $3 / 13^{*}$ \\
\hline Comparison group & $0(0 \div 6)$ & $6(0 \div 30)$ & $0 / 26$ & $15 / 26$ \\
\hline
\end{tabular}

Note: $\mathrm{Me}(\min -\max )$ - median (minimum-maximum recorded value); ${ }^{*}-$ significance of difference with the comparison group at $\mathrm{p}=0.041$

\section{DISCUSSION}

To date, it has been shown that laboratory tests in the practice of traumatology and orthopedics are prospective due to the fact that laboratory signs can be attributed to early preclinical predictors of pathological changes in bone tissue [16-18]. Thus, there are studies that demonstrate the possible value of determining indicators of the inflammatory response, including CRP, as prognostic tests for the formation of distraction regenerate [9, 19]. However, the proposed tests have been based only on experimental data without clinical applications.

A definite disadvantage of most of the laboratory tests proposed for the prognosis of disturbances in the formation of distraction regenerate is the lack of calculated informative values. Thus, the sensitivity of the test in the available works was determined only for the parameters of the immunogram [6].

We have chosen the CRP as a possible laboratory test for predicting the formation of distraction regenerate in our research. It is the most accessible and frequently used marker of the inflammatory response in clinical practice. Our retrospective analysis of clinical data found that maintaining the level of this marker in the initial period of the distraction stage within the range of up to $6 \mathrm{mg} / \mathrm{L}$ predicts an increased likelihood of developing cystic cavities in the regenerate by the end of the lengthening stage. The presence of such a relationship, the simplicity and availability of the test, as well as its rather acceptable predictive value (OR values), in our opinion, makes it quite reasonable for the use in clinical practice in combination with other studies.

It is important to note that the relationship we found between the level of the inflammatory response and the formation of a distraction regenerate demonstrates that completed osteogenesis is possible only in the presence of a certain level of early inflammatory response, which ensures further bone repair, including distraction osteogenesis.

Undoubtedly, the sample size and the data on its basis require further clinical verification. The quantitative characteristics of the test value might change; however, in our opinion, the choice of CRP as a test predictor of disturbances in the formation of distraction regenerate has been sufficiently justified. Moreover, to improve the predictive accuracy, this test could be used in conjunction with an ultrasound study [20]. Such a combination of diagnostic methods would enable to predict the development of cystic cavities of the distraction regenerate with high probability and to develop special technologies for early prevention of this complication, which to date, according to the literature data studied by us, are lacking. 


\section{CONCLUSION}

Preservation of the CRP level in the blood serum, not exceeding $6 \mathrm{mg} / \mathrm{l}$ during the first 10 days after the onset of distraction, is a prognostic sign indicating a high

probability of disturbance in the formation of distraction regenerate in patients with surgical lengthening of the lower limb bones with the Ilizarov method.

Funding The study was conducted within the framework of the theme "Optimization of the treatment process in patients with orthopedic and trauma pathology complicated and uncomplicated purulent infection, the development of new pathogenetically substantiated methods of surgical treatment aimed at the comprehensive restoration of the anatomical and functional state of the limb, general homeostasis and stable suppression of purulent and inflammatory phenomena" (State assignment for the implementation of research and development of the FSBI Ilizarov NMRC for TO of the Ministry of Health of Russia).

\section{REFERENCES}

1. Gubin A.V., Borzunov D.Y. Paradigma Ilizarova [Ilizarov’s paradigm]. Genij Ortopedii, 2012, no. 4, pp. 5-9. (in Russian)

2. Aranovich A.M., Stogov M.V., Kireeva E.A., Menshchikova T.I. Prognozirovanie i kontrol techeniia distraktsionnogo osteogeneza. Analiticheskii obzor [Prediction and control of distraction osteogenesis course. An analytical review]. Genij Ortopedii, 2019, vol. 25, no. 3, pp. 400-406. (in Russian)

3. Dolganova T.I., Novikov K.I., Kolesnikova E.S. Diagnosticheskaia znachimost podografii pri planirovanii kosmeticheskogo udlineniia goleni [Diagnostic significance of podography when planning cosmetic lengthening of the leg]. Fundamentalnye Issledovaniia, 2014, no. 7-3, pp. 482-486. (in Russian)

4. Menshchikova T.I., Borzunov D.Y., Dolganova T.I. Ultrazvukovoe skanirovanie distraktsionnogo regenerata pri polilokalnom udlinenii otlomkov u bolnykh s defektami dlinnykh kostei [Ultasound scanning the distraction regenerated bone during polylocal lengthening of fragments in patients with long bone defects]. Khirurgiia. Zhurnal im. N.I. Pirogova, 2014, no. 3, pp. 20-24. (in Russian)

5. Belokhvostikova T.S., Mikhalevich I.M. Immunologicheskoe prognozirovanie narushenii regeneratsii kostnoi tkani [Immunological prediction of the disorders of bone tissue regeneration]. Sibirskoe Meditsinskoe Obozrenie, 2018, no. 3 (111), pp. 98-104. (in Russian)

6. Leonova S.N., Kameka A.L., Rekhov A.V. Primenenie novykh tekhnologii v gnoinoi osteologii [Using new technologies in purulent osteology]. Acta Biomedica Scientifica, 2011, no. 4-1 (80), pp. 110-114. (in Russian)

7. Kovinka M.A., Stogov M.V., Tushina N.V., Gofman F.F. Dinamika biokhimicheskikh pokazatelei syvorotki krovi u patsientov s posttravmaticheskimi ukorocheniiami kostei konechnosti v protsesse lecheniia metodom Ilizarova [Dynamics of blood serum biochemical values in patients with limb bone posttraumatic shortenings in the process of treatment according to Ilizarov]. Genij Ortopedii, 2011, no. 4, pp. 35-38. (in Russian)

8. Talashova I.A., Kononovich N.A., Tushina N.V. Biokhimicheskie markery kosteobrazovaniia i vospaleniia u sobak pri udlinenii kostei goleni po Ilizarovu [Osteogenesis and inflammation biochemical markers in dogs when leg bone lengthening according to Ilizarov]. Veterinariia Kubani, 2016, no. 5, pp. 21-24. (in Russian)

9. Bazarnyi V.V. Laboratornyi monitoring distraktsionnogo kosteobrazovaniia [Laboratory monitoring of distraction osteogenesis]. Klinicheskaia Laboratornaia Diagnostika, 1999, no. 6, pp. 16-17. (in Russian)

10.Aranovich A.M., Trofimova E.V., Novikov K.I. Sposob otsenki techeniia distraktsionnogo osteosinteza [The way of evaluating the course of distraction osteosynthesis]. Patent RF no. 2291432 C1, GO1N 33/49 GO1N 33/50, 2005. (in Russian)

11.Compton J., Fragomen A., Rozbruch S.R. Skeletal Repair in Distraction Osteogenesis: Mechanisms and Enhancements. JBJS Rev., 2015, vol. 3, no. 8, pp. 01874474-201508000-00002. DOI: 10.2106/JBJS.RVW.N.00107.

12.Dhaliwal K., Kunchur R., Farhadieh R. Review of the cellular and biological principles of distraction osteogenesis: An in vivo bioreactor tissue engineering model. J. Plast. Reconstr. Aesthet. Surg., 2016, vol. 69, no. 2, pp. e19-e26. DOI: 10.1016/j.bjps.2015.11.003.

13.Stogov M.V., Luneva S.N., Novikov K.I. Growth factors in human serum during operative tibial lengthening with the Ilizarov method. J. Orthop. Res., 2013, vol. 31, no. 12, pp. 1966-1970. DOI: 10.1002/jor.22454.

14.Stogov M.V., Tushina N.V., Emanov A.A. Serum Concentration of Growth Factors in Dogs under Different Conditions of Distraction Osteogenesis. Bull. Exp. Biol. Med., 2015, vol. 160, no. 2, pp. 213-215. DOI: 10.1007/s10517-015-3131-2.

15. Rea L.M., Parker R.A. Designing and Conducting Research: A Comprehensive Guide. $4^{\text {th }}$ Edition. CA, San Francisco, Jossey-Bass. 2014.352 p.

16.Bauer T.W., Bedair H., Creech J.D., Deirmengian C., Eriksson H., Fillingham Y., Grigoryan G., Hickok N., Krenn V., Krenn V., Lazarinis S., Lidgren L., Lonner J., Odum S., Shah J., Shahi A., Shohat N., Tarabichi M., W-Dahl A., Wongworawat M.D. Hip and Knee Section, Diagnosis, Laboratory Tests: Proceedings of International Consensus on Orthopedic Infections. J. Arthroplasty, 2019, vol. 34, no. 2S, pp. S351-S359. DOI: 10.1016/j.arth.2018.09.019.

17.Dwyer M.K., Damsgaard C., Wadibia J., Wong G., Lazar D., Smith E., Talmo C., Bedair H. Laboratory Tests for Diagnosis of Chronic Periprosthetic Joint Infection Can Help Predict Outcomes of Two-Stage Exchange. J. Bone Joint Surg. Am., 2018, vol. 100, no. 12, pp. 1009-1015. DOI: 10.2106/JBJS.17.00599.

18.Tian A., Ma J., Feng K., Liu Z., Chen L., Jia H., Ma X. Reference markers of bone turnover for prediction of fracture: a metaanalysis. J. Orthop. Surg. Res., 2019, vol. 14, no. 1, pp. 68. DOI: 10.1186/s13018-019-1100-6.

19.Tushina N.V., Stogov M.V., Kononovich N.A., Emanov A.A. Prognoz dlitelnosti sozrevaniia distraktsionnogo regenerata [Prediction of the duration of distraction regenerated bone maturation]. Travmatologiia i Ortopediia Rossii, 2012, no. 1 (63), pp. 49-54. (in Russian)

20.Menshchikova T.I., Aranovich A.M. Otsenka aktivnosti reparativnogo osteogeneza distraktsionnogo regenerata bolshebertsovoi kosti s pomoshchiu sovremennykh ultrazvukovykh skanerov [Evaluation of reparative osteogenesis activity of tibial distraction regenerated bone using modern ultrasound scanners]. Genij Ortopedii, 2011, no. 4, pp. 101-105. (in Russian)

Received: 29.06.2020

\section{Information about the authors:}

1. Anna M. Aranovich, M.D., Ph.D., Professor,

Ilizarov National Medical Research Centre for Traumatology and Orthopedics, Kurgan, Russian Federation

2. Maksim V. Stogov, Ph.D. of Biological Sciences,

Ilizarov National Medical Research Centre for Traumatology and Orthopedics, Kurgan, Russian Federation, Email: stogo_off@list.ru

3. Natalia V. Tushina,

Ilizarov National Medical Research Centre for Traumatology and Orthopedics, Kurgan, Russian Federation

4. Elena A. Kireeva, Ph.D. of Biological Sciences,

Ilizarov National Medical Research Centre for Traumatology and Orthopedics, Kurgan, Russian Federation 